\title{
A MODEL FOR SPATIAL PLANNING OF SITE AND BUILDING USING BIM METHODOLOGY
}

\author{
Leonas USTINOVICHIUS ${ }^{\mathrm{a}}$, Aurelija PECKIENÉa ${ }^{\mathrm{a}}$, Vladimir POPOV ${ }^{\mathrm{b}}$ \\ ${ }^{a}$ Department of Construction Technology and Management, Faculty of Civil Engineering, \\ Vilnius Gediminas Technical University, Sauletekio al. 11, LT-10223 Vilnius, Lithuania \\ ${ }^{b}$ Department of Reinforced Concrete and Masonry Structures, Faculty of Civil Engineering, \\ Vilnius Gediminas Technical University, Saulètekio al. 11, LT-10223 Vilnius, Lithuania
}

Received 08 Jun 2016; accepted 28 Sep 2016

\begin{abstract}
In this day and age, as information technology develops at an intense pace, the construction sector cannot afford to fall behind. The term "building information modelling", or BIM, is now used increasingly more frequently. BIM covers the entire life span of a building - from planning to demolition. However, it should not be forgotten, that without a site, there can be no building. Territorial planning documents establish certain requirements for both the site itself and the buildings to be built within its boundaries. At present, territorial planning and building design are, for the most part, carried out as separate processes. In order to develop a more rational and effective process for the execution of a construction project, more attention should be paid to the stage of initial site and building planning (spatial planning). The requirements established by territorial planning documents must be taken into account at the initial site and building planning stage. A spatial planning model for buildings associated with a territorial planning system was developed as part of this study and could be used as a basis for further building information modelling.
\end{abstract}

Keywords: BIM, territorial planning, building, site, spatial planning, Matlab, artificial neural networks.

\section{Introduction}

In this day and age, as information technology develops at an intense pace, the construction sector cannot afford to fall behind. The term "building information modelling", or BIM, is now used increasingly more frequently. BIM covers the entire life span of a building - from planning to demolition. Building information modelling using BIM methodology is the future of the construction sector. However, it should not be forgotten, that without a site, there can be no building.

BIM models contain very detailed and accurate information about a building. In spite of this, such models are not necessarily associated with any geographical information. BIM is successfully applied in the stages of building design and construction, however, the application of BIM is still rare at the initial planning stage. For example, when planning a new building in an environment next to other structures, the information in the BIM model does not cover environmental information, i.e., information that would allow specialists to calculate insolation with respect to nearby trees or carry out an analysis of visibility through the building's windows (Rafiee et al. 2014).
The purpose of the present article is taking into account territorial planning documents and to create a spatial planning model for site and building using BIM.

\section{BIM and spatial planning}

In Lithuania, the term "spatial planning" is used in reference to urban or regional policy and is often related to the Lithuanian term "territorial planning" (Arimavičiūte 2011). Markevičienè (2015) defines spatial planning as a process that models the desired urban matrix based on the existing (inherited) matrix of the city's form (by preserving it, continuing it or devaluing it).

Cities are dynamic living organisms. This is why urban spatial planning has always been complicated. Today, our rapidly changing society has to foresee the needs of future city residents. Developers of spatial planning documentation find it very difficult to select the right urban development plans, especially taking into account the fact that cities are growing at an astonishing rate. Development plans are normally drawn up using two-dimensional (2D) maps having no hint of three-dimensional (3D) visualisations. Interaction between building and city

Corresponding author: Aurelija Peckienè

E-mail: aurelija.peckiene@vgtu.lt 
models is now one of the most analysed topics worldwide. A BIM model is limited to only showing the structure of a building, however, many important related objects from a building's are not represented in the model, e.g., street networks, plants, bodies of water, municipal utility structures, etc. (Mahdjoubi et al. 2015). One of the reasons to apply the BIM methodology in urban planning is the possibility to create contents with detailed information and to use this information for the assessment of the project (Dolas et al. 2013).

Three-dimensional (3D) data visualization is of critical importance in spatial planning. Planning the exterior and impact of new architectural objects on the environment in advance may help save financial resources before starting or finishing the construction works. This would also increase the involvement of the public in public deliberation processes (Cirulis, Brigmanis 2013).
Choosing the location for a building is also important for the project's success. The choice of a site affects nearly all aspects of design and construction processes, organizational, functional properties, harmoniousness, operating and economic efficiency, safety and, of course, aesthetic properties of the building (U.S. General Services Administration Public Buildings Service 2016).

There are many different tasks which can benefit from the incorporation of BIM. These benefits are documented as BIM Uses (The Computer Integrated Construction Research Group 2011). For this study most relevant BIM uses are: Existing Conditions Modeling, Programming, Site Analysis. Existing Conditions Modeling is the process in which a project team develops a 3D model of the existing conditions for a site, facilities on a site, or a specific area within a facility. This model can be developed in multiple ways: including laser scanning and

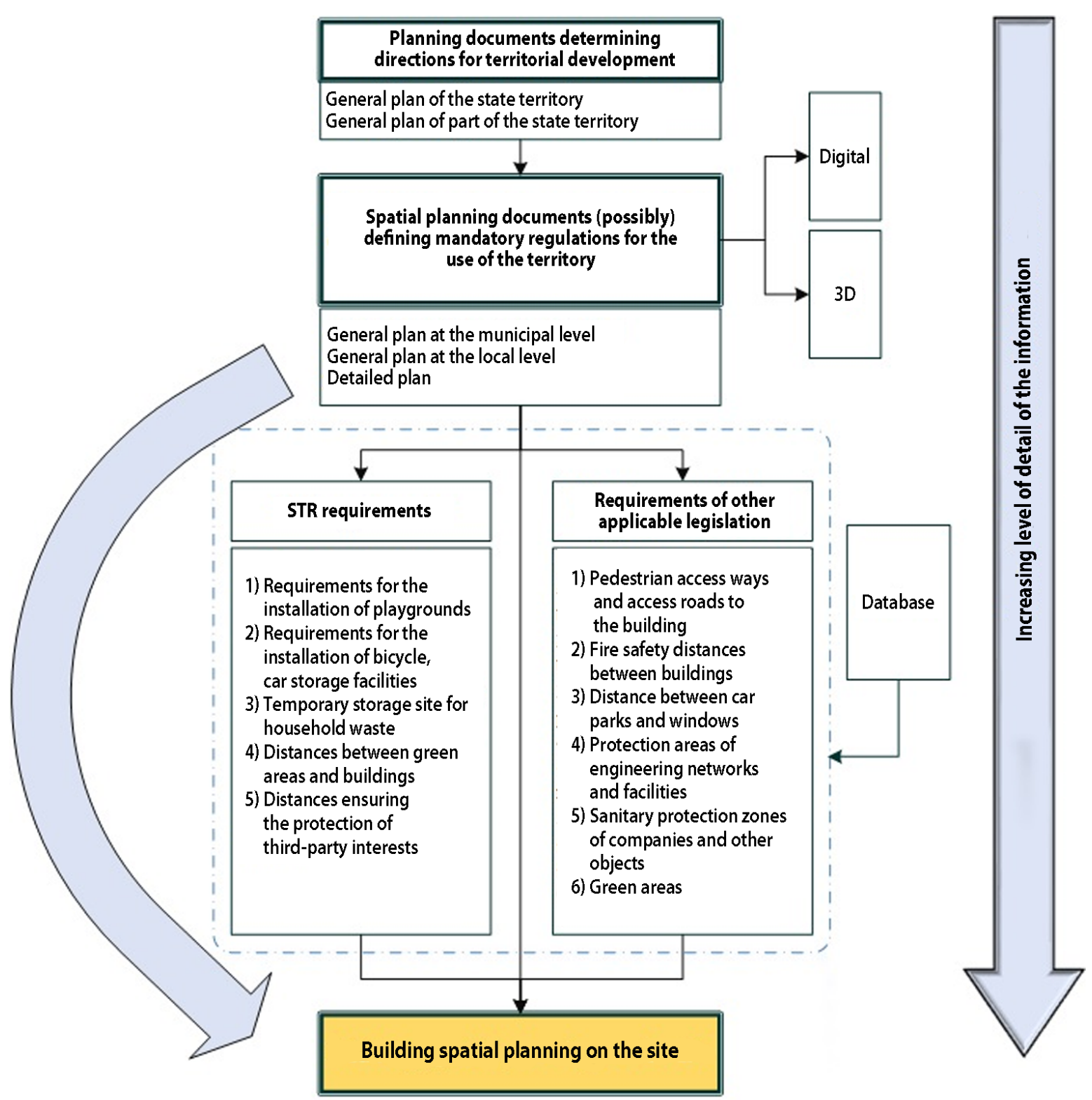

Fig. 1. Flowchart of links of site and building spatial planning with spatial planning documents and legal requirements 
conventional surveying techniques, depending on what is desired and what is most efficient. Once the model is constructed, it can be queried for information, whether it is for new construction or a modernization project (Foster 2011; The American Institute of Architects 2016; ZeibakShini et al. 2016). Programming is a process in which a spatial program is used to efficiently and accurately assess design performance in regard to spatial requirements. The developed BIM model allows the project team to analyze space and understand the complexity of space standards and regulations. Critical decisions are made in this phase of design and bring the most value to the project when needs and options are discussed with the client and the best approach is analyzed. Site Analysis is a process in which is determining the most optimal site location for a future project. The site data collected is used to first select the site and then position the building based on other criteria (The Computer Integrated Construction Research Group 2011).

At present, 3D city models are only beginning to develop. In publicly accessible information space can be found generated 3D city models of Berlin, New York, Chicago, Los Angeles, Singapore and others (Berlin business location center 2016; 3D CAD... 2016). Singapore aims to become the first "smart" country in the world (Peng, Khoo 2014). In Lithuania the scientists of Vilnius Gediminas technical university have created the first digital model prototype of student campus in Sauletekis (Popov 2016). 3D building models can be used for firefighting simulation (Chen et al. 2014), evacuation of people from fire, natural disasters or other cases (Lutz 2014), a low-energy building design, taking into account formed the city's energy consumption context (Niu et al. 2015).

The planning stage is especially important for the development and execution of a successful construction project. If all necessary requirements are considered during the planning stage, the risk of error and the need to change design solutions in later stages of the construction project are reduced. However, the BIM methodology is not currently widely applied in the planning stage. Building planning in three-dimensional space with BIM methodology could be used to produce significantly clearer conceptual solutions for the building design. However, implementing the method would not be easy: this would require the preparation of territorial planning documents in digital 3D format, and the entire framework of building regulation requirements would have to be collected and prepared for the appropriate format as well. This means the specific legal acts (laws, technical building regulations, hygiene norms, rules, etc.) that regulate the construction process and how they regulate it in a specific country. Schematic view of links of site and building spatial planning with the spatial planning documentation is presented in Figure 1. It is well-established that the construction process is regulated differently in different countries, thus creating a spatial planning model for site and buildings that functions based on the Lithuanian legal framework would be necessary.

\section{Components of the spatial planning process for site and buildings}

The spatial planning process can be defined as the planning of a building and its environment in a 3D environment by using modern computer technology and generating a virtual model that can be used and manipulated to imitate various real situations. The site and building spatial planning process consists of four main components (Fig. 2). Each of these components is made up of further elements.

It should be noted that during the planning stage, only the preliminary form of the building can be modified (changed). Requirements for the form of a building and various site planning norms are established by law, and solutions proposed by territorial planning documents cannot be changed during the planning stage, thus, these elements are constant.

Digital 3D territorial planning document. A territorial planning document in a digital $3 \mathrm{D}$ format is necessary for the practical implementation of the spatial planning process.

Preliminary solution for building form. Building form encompasses solutions for the positioning of the building on site, the building's volumetric form, and the entirety of the construction materials used on the building's exterior (walls, windows, roof). At the planning stage it is important these external partitions features: fire resistance, the number and placement of windows. Main requirements for fire resistance in Lithuania are set in Basic Fire Safety Requirements (2010) and Building Regulation STR 2.01.01(2):1999 "Fundamental building requirements. Fire safety" (1999). Requirements for windows are set in Building regulation STR 2.05.20:2006 "Windows and external doors" (2006) and Building Regulation STR 2.01.07:2003 "Internal and external protection against noise in buildings" (2003).

System of requirements for building form. Requirements for spatial form solutions in a spatial building model are established by territorial planning documents, building safety and use documents as well as other legal acts. The following requirements are established by territorial planning documents that affect the form of a

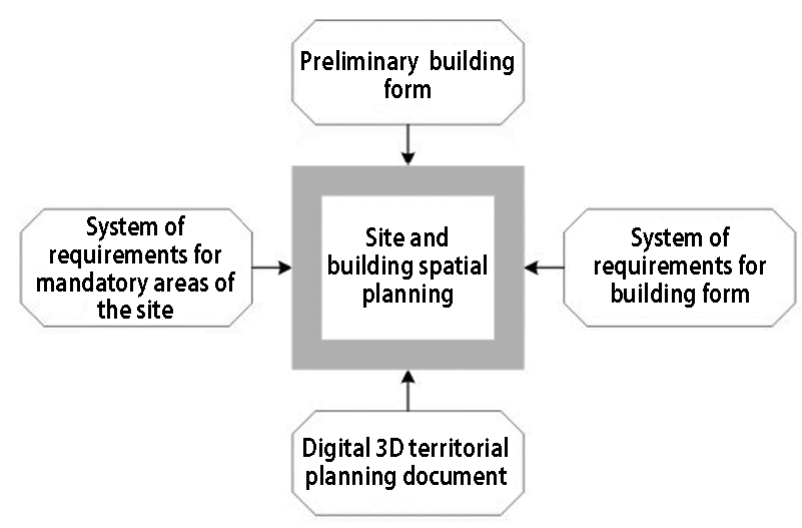

Fig. 2. Elements of the spatial planning process for site and buildings 
building: maximum height, maximum site coverage, maximum floor to site ratio, possible urban spatial structures, construction zone, limits, lines (Law of the Republic of Lithuania on Territorial Planning 2014; Territorial Planning Requirements 2014).

Building safety and use documents establish requirements related to the purpose of the planned building. The article focuses on residential and public buildings, so it will only discuss the requirements established for these types of buildings. Building safety and use documents establish the following requirements that affect the form of a building: maximum site coverage, requirements for the sound insulation class of the external partitions, insolation requirements, sanitary distances between buildings, distances between trees and buildings, distances that protect the interests of third parties. Main of these requirements are set in Building Regulation STR 2.02.01:2004 "Residential buildings" (2004), Building Regulation STR 2.02.02:2004 "Public buildings" (2004), Building Regulation STR 2.02.09:2005 "Single-family and duplex residential buildings" (2005), Building Regulation STR 2.01.07:2003 "Internal and external protection against noise in buildings" (2003).

Other legal acts establish the following requirements that affect the form of a building: fire resistance of the building's external shell, fire safety distances between buildings, distance between parking lots and windows, protection zones around building services and transportation routes (Basic Fire Safety Requirements 2010; Special Conditions for the Use of Land and Forest Land 1996).

System of requirements for establishing mandatory building site areas. Depending on the purpose of the building and other characteristics, regulatory documents establish mandatory sections of the building site that need to comply with certain requirements. Spatial building plans should take into account possibilities for planning these mandatory areas of the building site. The Building Regulation STR 2.02.01:2004 "Residential Buildings" establishes that minimal residential building site areas include: pedestrian access to the site and driveways, parking space, green spaces with playgrounds and exercise areas, recreational areas for seniors and disabled individuals, bicycle storage, an area for the temporary storage of domestic waste, building service structures (transformer stations, etc.). Easements should also be taken into consideration during the planning stage (Civil Code of the Republic of Lithuania 2000, Art. 4.111, part 1).

\section{Developing a spatial planning model for site and building}

The spatial planning model of a site and building is composed of four principal groups of solutions:

- building solutions;

- site solutions;

- building service solutions;

- transportation and access solutions.
During the planning stage, certain decisions must be made in each of the aforementioned groups. A detailed diagram of a building's spatial planning solutions is presented in Figure 3.

During the planning stage, a certain solution must be picked in the groups and subgroups shown in Figure 3. Next, each solution must be checked for compliance with requirements established by legal acts and territorial planning documents. It should be noted that the final spatial planning solution will only be acceptable if and only if all of the intermediary solutions are also acceptable. A diagram of the spatial site and building planning process is presented in Figure 4.

\section{Practical application of the model using Matlab and artificial neural networks}

At present, detailed planning in Lithuania does not use digital 3D methods. However, in order to theoretically demonstrate a practical example of the application of the model, we must establish a set of data for our theoretical detailed plan:

- regulated max. building height: $8-12 \mathrm{~m}$;

- regulated max. site coverage: 0.23 ;

- easements on site: none;

- protection zones: communications lines;

- min. green area: $25 \%$;

- degree of fire resistance of surrounding buildings: unknown (fire safety distances must then satisfy a single condition: minimum fire safety distance).

In order to demonstrate how the model works, examples of 30 building planning versions (solutions) were analysed for a building site that has the aforementioned characteristics. A diagram of the solutions tested in the example is presented in Figure 5, the examples are presented in Table 1.

Calculations completed with the Matlab mathematical system, which is based on a matrix data structure. The Matlab system is used to automatise calculation in many areas of science and technology. The system can be used with various application extension packages for data processing, signal analysis, images, neural networks, financial-economic calculation and other areas.

During the study, the Matlab system was used to write the interpreted source code. The results vector developed with the Matlab command shows in which column(s) the data sample satisfied the requirements (i.e., all results equal 1). This indicates that the building solution (a set of characteristics) presented in the column meets all applicable requirements.

Artificial neural networks can also be applied to the spatial planning process. Neural networks are biological systems that detect models, predict and learn. Artificial neural networks are used in modern model detection and prediction model generation based on large-scale historical databases. Artificial neural networks (ANN) are artificial intelligence systems designed to imitate the biological activity of the nervous system of the human brain: 


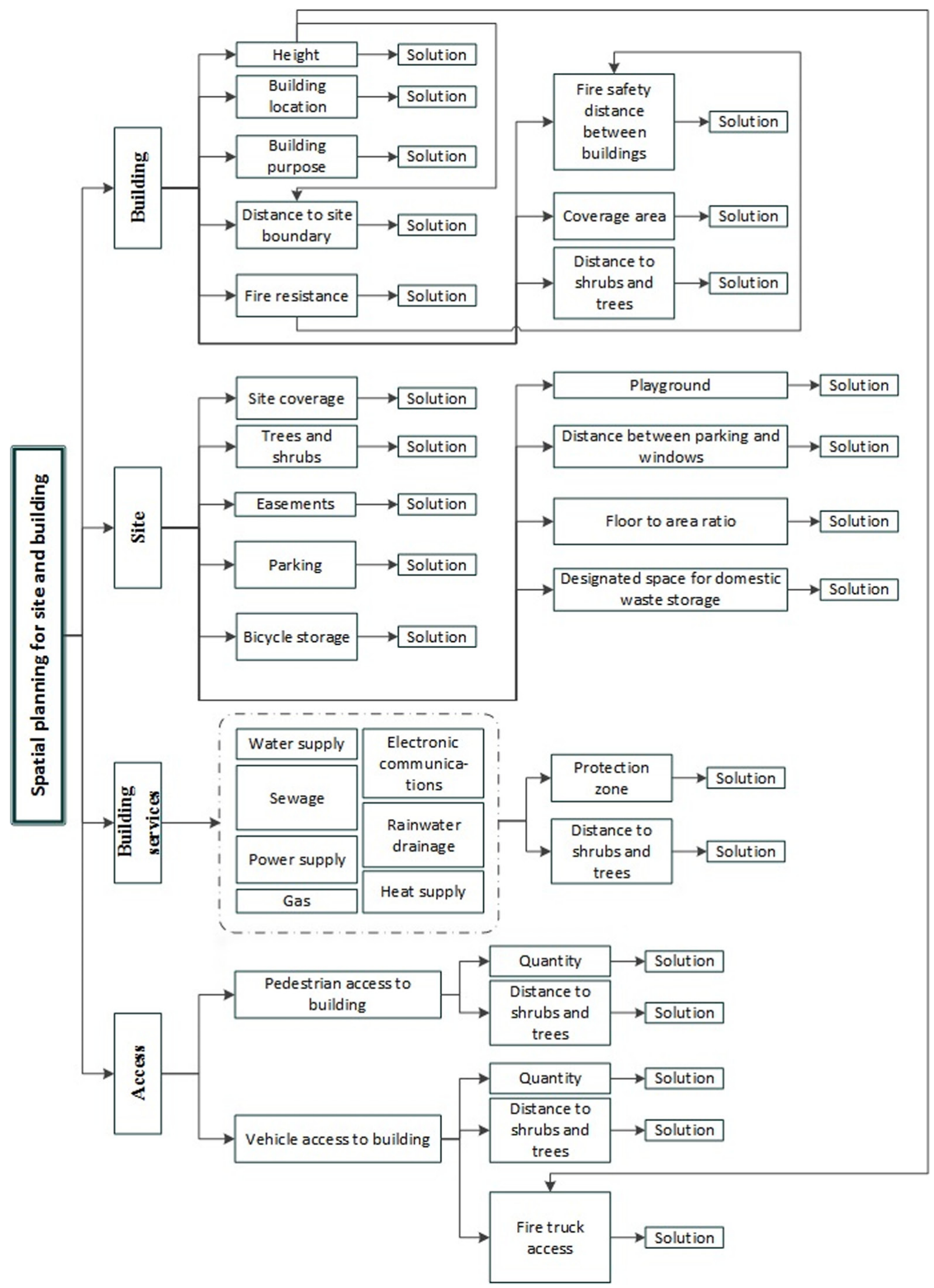

Fig. 3. Model for spatial site and building planning (diagram of solutions) 


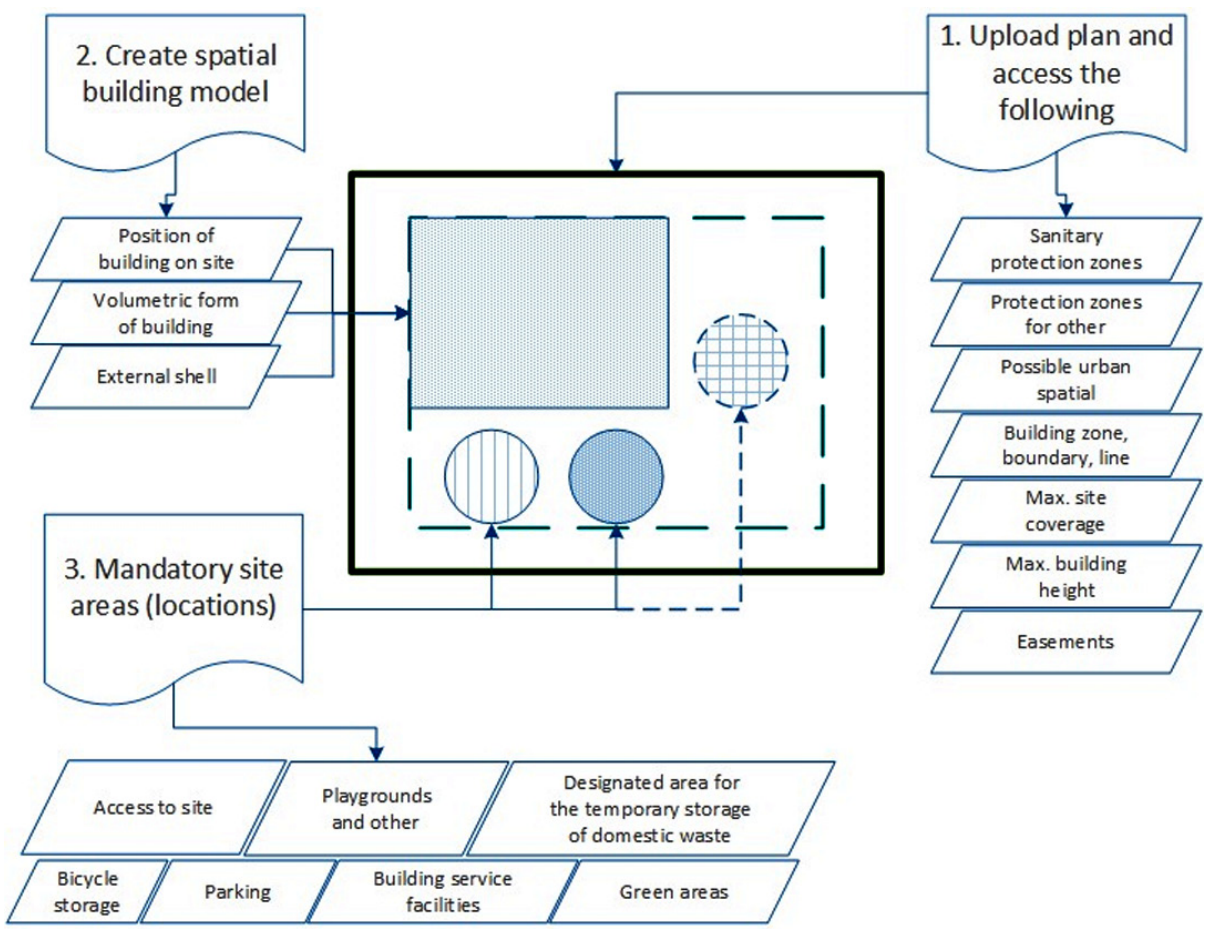

Fig. 4. Diagram of spatial site and building planning process

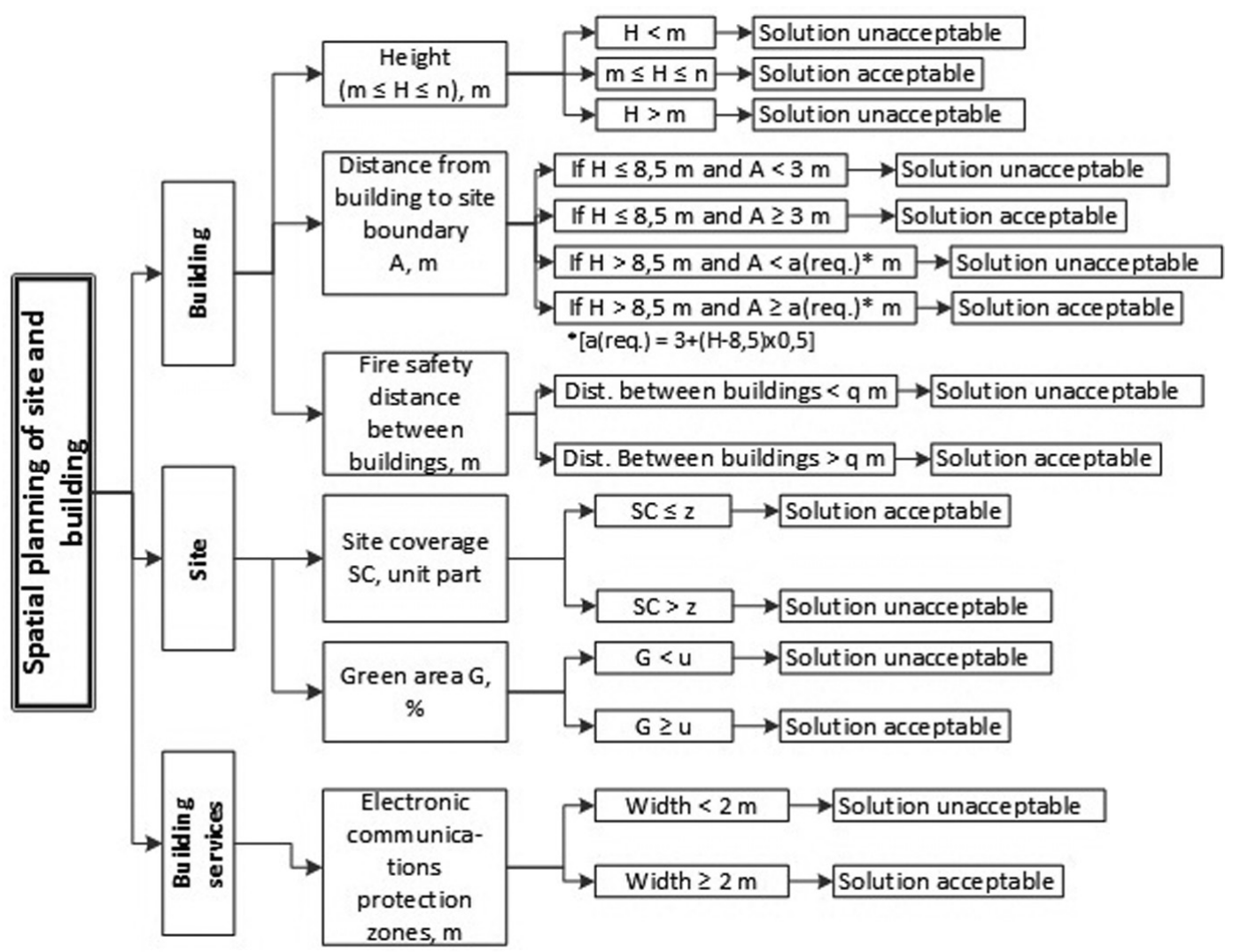

Fig. 5. Diagram of solutions tested in example 
Table 1. Initial data

\begin{tabular}{|c|c|c|c|c|c|c|c|c|c|c|c|c|}
\hline \multirow{2}{*}{ Solution } & \multicolumn{2}{|c|}{ Value } & \multicolumn{10}{|c|}{ Options (initial data) } \\
\hline & From & To & V1 & $\mathbf{V 2}$ & $\mathbf{V 3}$ & V4 & V5 & V6 & V7 & V8 & V9 & V10 \\
\hline Building height $\mathrm{H}, \mathrm{m}$ & 8 & 12 & 8 & 12 & 10 & 6 & 7 & 11 & 3 & 5 & 9 & 4 \\
\hline $\begin{array}{l}\text { Distance from building to } \\
\text { site boundary } \mathrm{A}, \mathrm{m}\end{array}$ & 3 & & 3 & 5 & 4 & 4 & 5 & 2 & 3 & 3 & 3 & 4 \\
\hline $\begin{array}{l}\text { Building site coverage SC, } \\
\text { unit part }\end{array}$ & & 0.23 & 0.2 & 0.2 & 0.4 & 0.2 & 0.17 & 0.3 & 0.3 & 0.6 & 0.21 & 0.2 \\
\hline Green area $\mathrm{G}, \%$ & 25 & & 24 & 26 & 50 & 13 & 45 & 15 & 67 & 23 & 34 & 10 \\
\hline $\begin{array}{l}\text { Fire safety distance } \\
\text { between buildings, } \mathrm{m}\end{array}$ & 6 & & 6 & 10 & 3 & 5 & 12 & 6 & 7 & 9 & 5 & 3 \\
\hline \multirow[t]{2}{*}{$\begin{array}{l}\text { Electronic communications } \\
\text { protection zones, } \mathrm{m}\end{array}$} & 2 & & 2 & 2.5 & 1 & 1.6 & 2 & 4 & 1.3 & 1.7 & 2.2 & 2.7 \\
\hline & & & V11 & V12 & V13 & V14 & V15 & V16 & V17 & V18 & V19 & V20 \\
\hline Building height $\mathrm{H}, \mathrm{m}$ & 8 & 12 & 8 & 9 & 10 & 10 & 12 & 13 & 9 & 8 & 11 & 12 \\
\hline $\begin{array}{l}\text { Distance from building to } \\
\text { site boundary A, m }\end{array}$ & 3 & & 3 & 3.5 & 3 & 3.6 & 5 & 2 & 3.3 & 3 & 3.5 & 3 \\
\hline $\begin{array}{l}\text { Building site coverage SC, } \\
\text { unit part }\end{array}$ & & 0.23 & 0.23 & 0.2 & 0.22 & 0.2 & 0.2 & 0.3 & 0.2 & 0.23 & 0.21 & 0.2 \\
\hline Green area $\mathrm{G}, \%$ & 25 & & 25 & 26 & 27 & 25 & 26 & 20 & 30 & 25 & 27 & 30 \\
\hline $\begin{array}{l}\text { Fire safety distance } \\
\text { between buildings, m }\end{array}$ & 6 & & 6 & 7 & 7 & 8 & 6 & 3 & 8 & 6 & 7 & 6.5 \\
\hline \multirow[t]{2}{*}{$\begin{array}{l}\text { Electronic communications } \\
\text { protection zones, } \mathrm{m}\end{array}$} & 2 & & 2 & 2 & 2.5 & 2.2 & 2.1 & 1 & 2.2 & 2 & 3 & 2.3 \\
\hline & & & V21 & $\mathbf{V 2 2}$ & $\mathbf{V 2 3}$ & V24 & V25 & V26 & V27 & V28 & V29 & V30 \\
\hline Building height $\mathrm{H}, \mathrm{m}$ & 8 & 12 & 1 & 20 & 10 & 0.1 & 50 & 2 & 40 & 60 & 21 & 34 \\
\hline $\begin{array}{l}\text { Distance from building to } \\
\text { site boundary A, m }\end{array}$ & 3 & & 1 & 0 & 0 & 0.1 & 2 & 2 & 10 & 4 & 2 & 7 \\
\hline $\begin{array}{l}\text { Building site coverage SC, } \\
\text { unit part }\end{array}$ & & 0.23 & 1 & 1 & 0.5 & 1 & 0.5 & 0.2 & 1 & 0.23 & 0.15 & 0.2 \\
\hline Green area $\mathrm{G}, \%$ & 25 & & 1 & 3 & 10 & 0.1 & 11 & 2 & 70 & 60 & 34 & 45 \\
\hline $\begin{array}{l}\text { Fire safety distance } \\
\text { between buildings, } \mathrm{m}\end{array}$ & 6 & & 1 & 0 & 1 & 0.1 & 0.5 & 2 & 10 & 4 & 3 & 4 \\
\hline $\begin{array}{l}\text { Electronic communications } \\
\text { protection zones, } \mathrm{m}\end{array}$ & 2 & & 1 & 0 & 1 & 0.1 & 0 & 2 & 8 & 10 & 2 & 7 \\
\hline
\end{tabular}

leaning, thinking, data storage, recollection and recognition. These networks are implemented through software. Even though researchers are still far from a complete understanding of how the human brain works, artificial neural networks can already carry out certain actions just as the human mind does (Mandryka, Česnulevičius 2009).

In the field of construction, artificial neural networks are applied in:

- Prediction and cost projection. In this area, artificial neural networks are applied in projecting the possible costs of a design solution, construction costs, changes in the construction budget, project cash flow, construction demand, productivity of the labour force, groundwork operations, the applicability of new technology and organisational effectiveness.

- Construction project optimisation. In this area, ANN are applied in order to optimise construction site planning and the duration of the construction process.
- Decision-making. In this area, ANN are applied in order to make decisions in the context of modular design.

- Classification or selection. In this area, ANN are applied to the selection of crane types and models, estimating concrete strength and calculating construction project productivity (Jain, Pathak 2014).

An artificial neural network can generate a model from examples. This is very relevant to the present case because every site and every building is different. As the neural network learns, it will pick up errors more easily and quickly and identify as well as suggest possible solutions for fixing them in consideration of planning decisions made in previous building and site planning solutions.

Initial data is necessary for setting up a neural network model. This data is referred to as input signals. In this case, input signals are identified and described by 


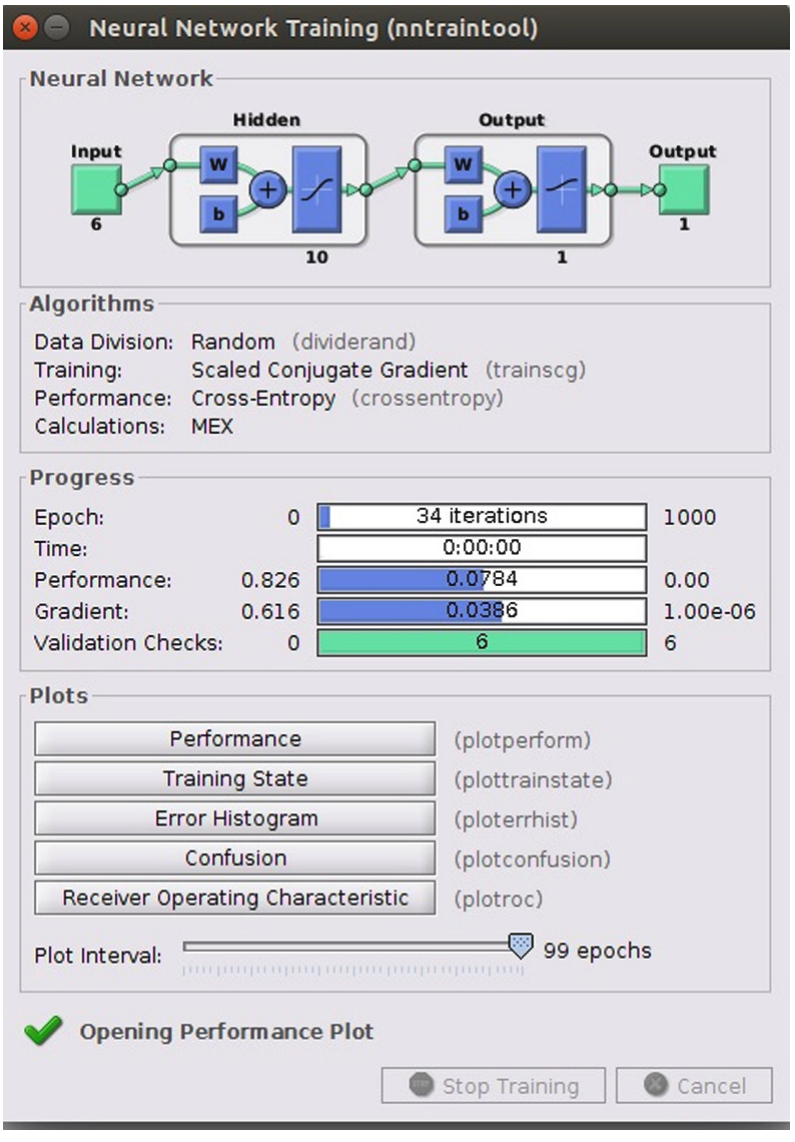

Fig. 6. Training progress of the neural network

spatial planning characteristics. The more initial input data (hundreds, even thousands of entries), the more effectively and accurately the neural network will operate. All of this would be achievable if the proposed spatial planning model were to be developed and implemented in reality, allowing specialists to plan and contribute to the database. This study proposes a basic neural network model for building and site planning based on a certain portion of the input signals.

The proposed neural network was developed in the Matlab system. The training progress of the neural network is show in Figure 6. If the network training results are unacceptable (the network makes a lot of mistakes), it can be trained anew, increasing the number of neurons or increasing the quantity of input data it is taught with. An obviously unacceptable solution is entered into the network in order to check how it works, e.g.: all initial data is equal $[1 ; 1 ; 1 ; 1 ; 1 ; 1]$. Result: ans $=0.0053$ (see Fig. 7). If a clearly correct example is entered into the system based on initial data $[8 ; 3 ; 0.23 ; 26 ; 7 ; 2]$, the neural network produces the following result: ans $=0.8796$ (see Fig. 8).

The neural network developed as part of this study has produced adequate results. The result produced by a clearly incorrect building solution amounted to 0.0053 , which is close to 0 . The result produced by a clearly correct building solution amounted to 0.8796 , which is close to 1 . No such results were produced during the study,

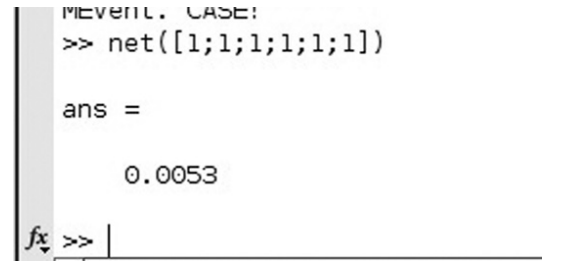

Fig. 7. Neural network answer with a clearly incorrect solution

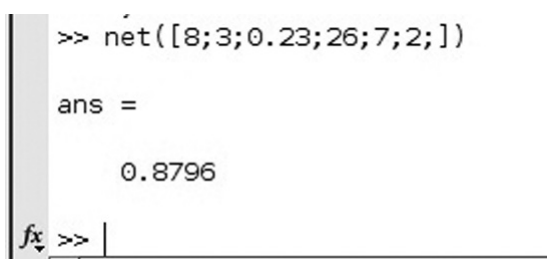

Fig. 8. Neural network answer with a clearly correct solution

however, in some cases, the model can produce a result of 0.5 . This would make it unclear whether the solution is to be viewed as correct or incorrect. In this case, the solution should be assessed organically (using human resources) and the neural network should undergo additional training. However, as time goes by and as databases and, respectively, the reliability of the neural network increases, such cases should occur increasingly less frequently.

\section{Conclusions}

1. A conceptual model for spatial site and building planning was developed and proposed for assessing various solutions with regard to a proposed building, building site, building services and transportation/ access as well as communications solutions. During the planning stage, a certain solution must be selected in each solution group and subgroup. Next, each solution must be checked for compliance with requirements established by law and territorial planning documents. It should be noted that the final spatial planning solution will only be acceptable if and only if all of the intermediary solutions are also acceptable.

2. Because every building site and every building is different, it is important that the model is capable of learning on its own. This would facilitate the faster modelling and planning of a site and building, the formation of a model based on previous examples. As the neural network learns, it will pick up errors more easily and quickly and identify as well as suggest possible solutions for fixing them in consideration of planning decisions made in previous building and site planning solutions. For this reason, the study presents a simplified example of how to apply the model in a practical sense using Matlab and artificial neural networks.

3. The neural network developed based on a certain portion of the proposed model produced acceptable 
results. In future practice, if the neural network produces ambiguous results, the solution should be assessed organically (using human resources) and the neural network should undergo additional training. However, as time goes by and as databases and, respectively, the reliability of the neural network increases, such cases should occur increasingly less frequently.

\section{References}

3D CAD browser. 2016. New York City, Manhattan 3D Model [online], [cited 20 February 2016]. Available from Internet: http://www.3dcadbrowser.com/download. aspx? $3 \mathrm{dmodel}=40454$

Arimavičiūtè, M. 2011. Savivaldybių strateginès plètros planavimas užsienio šalių pavyzdžiu [Municipal strategic development planning in foreign countries as an example], Socialiniu mokslu studijos [Studies of Social Sciences] 3(1): 59-76 (in Lithuanian).

Basic Fire Safety Requirements. 2010. Approved by order No. 1-338 of the Head of the Fire Safety and Rescue Department under the Ministry of Internal Affairs of 07 December 2010 (in Lithuanian).

Berlin business location center. 2016. Berlin 3D city model [online], [cited 20 February 2016]. Available from Internet: http:/www.businesslocationcenter.de/en/berlin-economicatlas/the-project

Building Regulation STR 2.01.01(2):1999 "Fundamental building requirements. Fire safety". 1999. Approved by order No. 422 of the Minister of the Republic of Lithuania Ministry of Environment of 27 December 1999 (State Gazette, 25/02/2000, No. 17-424) (in Lithuanian).

Building Regulation STR 2.01.07:2003 "Internal and external protection against noise in buildings". 2003. Approved by order No. 387 of the Minister of the Republic of Lithuania Ministry of Environment of 17 July 2003 (State Gazette, 2003, No. 79-3614) (in Lithuanian).

Building Regulation STR 2.02.01:2004 "Residential buildings". 2004. Approved by order No. 705 of the Minister of the Republic of Lithuania Ministry of Environment of 24 December 2003 (State Gazette, 12/02/2004, No. 23-721) (in Lithuanian).

Building Regulation STR 2.02.02:2004 "Public buildings". 2004. Approved by order No. D1-91 of the Minister of the Republic of Lithuania Ministry of Environment of 27 February 2004 (State Gazette, 15/04/2004, No. 54-1851) (in Lithuanian).

Building Regulation STR 2.02.09:2005 "Single-family and duplex residential buildings". 2005. Approved by order No. D1-338 of the Minister of the Republic of Lithuania Ministry of Environment of 01 July 2005 (State Gazette, 2005, No. 93-3464) (in Lithuanian).

Building Regulation STR 2.05.20:2006 "Windows and external doors". 2006. Approved by order No. D1-62 of the Minister of the Republic of Lithuania Ministry of Environment of 01 February 2006 (State Gazette, 13/02/2006, No. 18643) (in Lithuanian).

Chen, L. C.; Wu, C. H.; Shen, T. S.; Chou, C. C. 2014. The application of geometric network models and building information models in geospatial environments for firefighting simulations, Computers, Environment and Urban Systems 45: 1-12. http://dx.doi.org/10.1016/j.compenvurbsys.2014.01.003

Cirulis, A.; Brigmanis, K. B. 2013. 3D outdoor augmented reality for architecture and urban planning, Procedia Computer Science 25: 71-79.

http://dx.doi.org/10.1016/j.procs.2013.11.009
Civil Code of the Republic of Lithuania. 2000. State Gazette, 2000, No. 74-2262 (in Lithuanian).

Dolas, C.; Dieckmann, A.; Russell, P. 2013. Building your own urban tool kit, in Computation and Performance - Proceedings of the 31 ${ }^{\text {st }}$ eCAADe Conference, 18-20 September 2013, Delft, Netherlands.

Foster, J. 2011. PointKnown cited in Autodesk Energy Modeling White Paper: BIM [online], [cited 3 April 2016]. Available from Internet: http://frombulator.com/2011/06/ pointknown-cited-in-autodesk-reality-capture-white-paper-bim/.

Jain, M.; Pathak, K. K. 2014. Application of artificial neural network in construction engineering and management - A review, International Journal of Engineering Technology, Management and Applied Sciences 2(3): 134-142.

Law of the Republic of Lithuania on Territorial Planning. 2014. State Gazette, 1995, No. 107-2391. Amended version of law: from 01 January 2014, No. XII-407, 27/06/2013, State Gazette, 2013, No. 76-3824 (16/07/2013).

Mahdjoubi, L.; Brebbia, C. A.; Laing, R. 2015. Building Information Modelling (BIM) in design, construction and operations. Southampton, Boston: WIT Press. 626 p. http://dx.doi.org/10.2495/BIM15

Mandryka, R.; Česnulevičius, A. 2009. Mechaninių komponentų gamybos kaštų prognozavimo metodai [Cost forecasting methods for mechanical components' manufacturing], in Jaunuju mokslininku ir studentu konferencija ,,Technologijos mokslai šiandien ir rytoj " [Young scientists and students conference "Technological sciences today and tomorrow"], 4 December 2009, Panevėžys, Lithuania (in Lithuanian).

Markevičienė, J. 2015. Miestas kaip spąstai: apie normas ir laisves, kuriant miesto architektūrą [City as a trap: about norms and freedoms in development of urban architecture], Architektūros kokybès kriterijai: Mokslo straipsniu rinkinys [Architectural quality criteria: scientific collection of articles]. Vilnius: Technika. 240 p. (in Lithuanian).

Niu, A.; Pan, W.; Zhao, Y. 2015. A BIM-GIS integrated webbased visualization system for low energy building design, Procedia Engineering 121: 2184-2192. http://dx.doi.org/10.1016/j.proeng.2015.09.091

Peng, S. K.; Khoo, V. 2014. Mapping Singapore in 3D [online], [cited 3 April 2016]. Available from Internet:

http:/www.clc.gov.sg/documents/books/Mapping\%20Singapore $\% 20$ in $\% 203$ D.pdf

Popov, V. 2016. VGTU mokslininkai kuria pirmaji Lietuvoje skaitmenini miesteli [VGTU scientists are developing the first digital city in Lithuania] [online], [cited 20 June 2016]. Available from Internet: http://naujienos.vgtu.lt/ naujienos/universiteto-pulsas/vgtu-mokslininkai-kuriapirmaji-lietuvoje-skaitmenini-miesteli/165052 (in Lithuanian)

Rafiee, A.; Dias, E.; Fruijtier, S.; Scholten, H. 2014. From BIM to geo-analysis: view coverage and shadow analysis by BIM/GIS integration, Procedia Environmental Sciences 22: $397-402$.

http://dx.doi.org/10.1016/j.proenv.2014.11.037

Special Conditions for the Use of Land and Forest Land. 1996. Approved by resolution No. 343 of the Government of the Republic of Lithuania of 12 May 1992 (in Lithuanian).

Territorial Planning Requirements. 2014. Approved by order No. D1-7 of the Minister of the Republic of Lithuania Ministry of Environment of 02 January 2014 (in Lithuanian).

The American Institute of Architects. 2016. Innovative capture and modeling of existing building conditions using $3 D$ laser scanning online], [cited 3 April 2016]. Available from Internet: http://www.aia.org/aiaucmp/groups/aia/documents/pdf/aiab081592.pdf. 
The Computer Integrated Construction Research Group. 2011. Building Information Modeling project execution planning guide. The Pennsylvania State University, USA. 125 p.

U.S. General Services Administration Public Buildings Service. 2016. The site selection guide [online], [cited 3 April 2016]. Available from Internet:

http://www.gsa.gov/graphics/pbs/GSA_Site_Selection Guide_R2-sY2-i_0Z5RDZ-i34K-pR.pdf
Zeibak-Shini, R.; Sacks, R.; Ma, L.; Filin, S. 2016. Towards generation of as-damaged BIM models using laser-scanning and as-built BIM: First estimate of as-damaged locations of reinforced concrete frame members in masonry infill structures, Advanced Engineering Informatics 30(3): 312-326. http://dx.doi.org/10.1016/j.aei.2016.04.001

Leonas USTINOVICHIUS. Professor Dr Habil at Vilnius Gediminas Technical University and Bialystok University of Technology. Education: Industrial and civil engineering, construction engineer, VISI (VGTU), 1982; Candidate of technical sciences Dnepropetrovsk ISI, 1989; Associate professor, VGTU, 1993; Doctor of technical sciences, VGTU, 1994; Doctor habilitatus, VGTU, 2003; Professor, VGTU, 2007. Research interests: multicriteria evaluation and automated programming of technological decision in construction, operational research methods, technology of construction process, quantitative and qualitative decision making methods, organization and performance of construction firm.

Aurelija PECKIENĖ. PhD student in Construction Technology and Management Department. Vilnius Gediminas Technical University. Research interests: risk management, decision-making theory, automation in design, spatial planning.

Vladimir POPOV. Dr Assoc. Prof. at Department of Reinforced Concrete and Masonry Structures Vilnius Gediminas Technical University. Doctor of Technical Sciences (civil engineering), 1994. Publications: the author and co-author of 5 textbooks for students, 1 patent and more than 40 scientific publications. Research interests: computer-aided design systems and methods, Building Information Modelling and Integrated Design Technology, general theory of reinforced concrete and masonry, building structural analysis by finite element method. 